\title{
STOCK ENHANCEMENT IN INDONESIAN LAKE AND RESERVOIRS FISHERIES
}

\author{
Endi Setiadi Kartamihardja \\ Research Center for Fisheries Management and Fish Resources Conservation \\ Received March 27-2012; Received in revised form December 3-2012; Accepted December 4-2012 \\ E-mail: endi_prpt@indo.net.id
}

\begin{abstract}
A total water surface area of lakes and reservoirs of Indonesia is 2.3 million hectares. To increase fish production in Indonesian lakes and reservoirs, fish stock enhancement were practiced. A review on fish stock enhancement in Indonesian lakes and reservoirs was conducted. Some species used in stock enhancement were reviewed, and the causes of program success or failure were analyzed in an attempt to determine the best approach for future stocking. Since 2000 the success of the project on fish stock enhancement were supported by basic research on diet, ecological niche, life cycle and behavior of the species stocked. Recent successes in fish stock enhancement are mainly determined by species which can be reproduced naturally in the water bodies. Nile tilapia (Oreochromis niloticus), Siamese cat fish (Pangasionodon hypophthalmus) and small carp (bilih, Mystacoleucus padangensis), an endemic species are the species have best performances in the increasing fish production significantly. Milk fish (Chanos chanos) stock enhancement can be used to mitigate the negative impact of cage culture in the reservoir. While grass carp (Ctenopharyngodon idellus) has been successful in controlling aquatic weed, Eichhornia crassipes in some lakes. Management of fish stock enhancement including providing quality and quantity of seeds, regulating of fish catch, developin $g$ of market system, institution and fisheries co-management have supported a steady yearly increase in yield. The governments should take the initiative in protection of genetic diversity, especially in stock enhancement of lakes inhabited by endemic and or threatened species, such as lakes in Sulawesi and Papua Island.
\end{abstract}

Key words: Stock enhancement, management, fisheries, lake, reservoir, Indonesia

\section{INTRODUCTION}

A total water surface area of inland open waters of Indonesia is 14.3 million hectares; compose of rivers and flood plains 12 million hectares, lakes 1.8 million hectares and man-made lakes or reservoirs 0.5 million hectares. Indonesia has around 840 lakes and 735 "situ" (small lakes) and around 162 reservoirs (Kartamihardja, 2006). About $80 \%$ of the total area of reservoirs is located in Java Island, an island densely population, while the lakes were mostly distributed in large island, i.e., Sumatera, Kalimantan, Sulawesi, and Papua (Sukadi \& Kartamihardja, 1995).

The Indonesian lakes and reservoirs were utilized by multi-sectors such as source of water for industrial and household, agriculture irrigation, hydro-electric power generation, fisheries, and eco-tourism. Fisheries activities in lakes have been conducted for a long time ago, while reservoir fisheries have been developed since the reservoirs impounded. Stock enhancement activity in the mean of fish introduction has been conducted since Dutch colonization. Only some fish have been established and affected the fish yield (Sarnita, 1986).
In 2009, the Ministry of Marine Affairs and Fisheries of Republic of Indonesia has a vision: "Indonesia has become the biggest fisheries production by the year 2015". As consequences the fish production in lakes and reservoirs should also be increased to support this vision. Increasing the fish production in lakes and reservoirs can be done through stock enhancement techniques.

This paper aimed to review the fish stock enhancement practiced, and to analyze the causes of program success or failure in an attempt to determine the best approach for future stocking.

\section{MATERIALS AND METHODS}

Data and information on fish stock enhancement were collected based on literature review and research results conducted by the Agency for Marine and Fisheries Research and Development. Some cases of scientific bases on stock enhancement which affected significantly on the increasing fish yield as well as mitigating and rehabilitation of the waters environment were also analyzed. Secondary data on trend of fish production were collected from Indonesian Fisheries Statistical Data of Ministry of Marine Affairs and Fisheries, Republic of Indonesia. The data were 
tabulated and then analyzed descriptively using the Excel program. Some factors causing the stock enhancement program success or failure were identified and discussed in attempt to determine the best approach for future development.

\section{RESULTS}

\section{Limnological Characteristics of Lakes and Reservoirs}

The latest limnological characteristics of major lakes and reservoirs has been reviewed through Expedition Indodanau in 1995 (Lehmusluoto \& Machbub, 1997), after that there is no comprehensive research conducted, only sporadically done for some lakes and reservoirs when begin to support fisheries Kartamihardja et al., 1992). The morphometric and trophic level of major lakes is presented in Table 1.
The large and deep lake mostly classified into volcanic, tectonic or crater lake which are located in Sumatera, Sulawesi and Papua. Toba Lake is the largest lake with a surface water area of 112,000 hectares, while the Towuti Lake is the deepest lake $(590 \mathrm{~m})$ in Indonesia. Most of the tectonic, volcanic and crater lakes are low productive lakes which were classified into oligotrophic and mesotrophic lakes. On the contrary, the floodplain lakes, which mostly located in Kalimantan are shallow productive lakes and were classified into meso- to eutrophic waters. Trophic level of some lakes, such as Toba and Maninjau Lakes tend to increase as a result of waste loading from intensive cage fish culture. Generally, the reservoirs are more productive than the lakes. Morphometric characters and trophic level of man-made lakes or reservoirs is presented in Table 2.

Table 1. Morphometric and trophic level of major Indonesian Lakes (Kartamihardja, 2009; Lehmusluoto \& Machbub, 1977; Sukadi \& Kartamihardja, 1995)

\begin{tabular}{|c|c|c|c|c|c|}
\hline Island / Lake & Area (ha) & Depth (m) & Altitude (m asl) & Type & Trophic Level \\
\hline \multicolumn{6}{|l|}{ SUMATERA: } \\
\hline Laut Tawar & 7,000 & 80 & 1100 & Tectonic & Mesotrophic \\
\hline Toba & 112,000 & 500 & 905 & Tecto-Volcanic & Mesotrophic \\
\hline Maninjau & 9,790 & 180 & 459 & Caldera & Mesotrophic \\
\hline Singkarak & 10,780 & 80 & 360 & Tectonic & Mesotrophic \\
\hline Diatas & 3,600 & 36 & 1100 & Tectonic & Oligotrophic \\
\hline Dibawah & 1,200 & 80 & 800 & Tectonic & Mesotrophic \\
\hline Ranau & 12,590 & 229 & 540 & Tectonic & Mesotrophic \\
\hline Kerinci & 6,000 & 45 & 900 & Tectonic & Mesotrophic \\
\hline \multicolumn{6}{|c|}{ KALIMANTAN: } \\
\hline Luar & 15,000 & 6 & 25 & Floodplain & Mesotrophic \\
\hline Genali & 18,000 & 6 & 24 & Floodplain & Eutrophic \\
\hline Sembuluh & 7,600 & 10 & 15 & Floodplain & Mesotrophic \\
\hline Jempang & 15,000 & 5 & 10 & Floodplain & Eutrophic \\
\hline Semayang & 12,000 & 5 & 10 & Floodplain & Eutrophic \\
\hline Melintang & 9,000 & 5 & 10 & Floodplain & Eutrophic \\
\hline \multicolumn{6}{|l|}{ SULAWESI: } \\
\hline Limboto & 3,500 & 4 & 15 & Floodplain & Eutrophic \\
\hline Tondano & 6,000 & 30 & 600 & Crater & Mesotrophic \\
\hline Poso & 32,300 & 450 & 485 & Tectonic & Oligotrophic \\
\hline Lindu & 3,150 & 100 & 9 & Tectonic & Oligotrophic \\
\hline Tempe & 10,000 & 5 & 5 & Floodplain & Eutrophic \\
\hline Towuti & 56,100 & 203 & 382 & Tectonic & Oligotrophic \\
\hline Matana & 16,500 & 600 & 293 & Tectonic & Oligotrophic \\
\hline \multicolumn{6}{|l|}{ B A L I: } \\
\hline Batur & 1,590 & 80 & 1031 & Caldera & Oligotrophic \\
\hline \multicolumn{6}{|c|}{ IRIAN/PAPUA: } \\
\hline Sentani & 9,360 & 50 & 70 & Landslide & Mesotrophic \\
\hline Paniai & 14,150 & 20 & 1742 & Tectonic & Oligotrophic \\
\hline Ayamaru & 2,200 & td & 250 & Tectonic & Oligotrophic \\
\hline Yamur & 3,750 & td & 90 & Tectonic & Oligotrophic \\
\hline Tage & 2,400 & td & 1750 & Tectonic & Oligotrophic \\
\hline Tigi & 3,000 & td & 1740 & Tectonic & Oligotrophic \\
\hline
\end{tabular}


Table 2. Morphometric and trophic level of major Indonesian reservoirs (Kartamihardja, 2009; Lehmusluoto\&Machbub, 1977; Sukadi \& Kartamihardja, 1995)

\begin{tabular}{|c|c|c|c|c|c|}
\hline Province/Reservoir & $\begin{array}{l}\text { Area } \\
\text { (ha) }\end{array}$ & Depth (m) & Altitude (m asl) & Trophic Level & $\begin{array}{c}\text { Impounded- } \\
\text { Purposes }\end{array}$ \\
\hline \multicolumn{6}{|l|}{ West Jawa: } \\
\hline Saguling & 5340 & 90 & 625 & Hyper-eutrophic & $1985-\mathrm{FEI}$ \\
\hline Cirata & 6200 & 106 & 250 & Hyper-eutrophic & $1987-\mathrm{FEI}$ \\
\hline Jatiluhur & 8300 & 95 & 110 & Hyper-eutrophic & 1965-DFEl \\
\hline Darma & 400 & 12 & 70 & Meso-eutrophic & $1962-1$ \\
\hline \multicolumn{6}{|l|}{ Central Jawa: } \\
\hline Wonogiri & 6480 & 28 & 140 & Meso-eutrophic & $1981-I F E$ \\
\hline Wadaslintang & 1460 & 85 & 115 & Mesotrophic & $1987-I F E$ \\
\hline Kedungombo & 6100 & 50 & 100 & Mesotrophic & $1989-$ IFE \\
\hline Mrica & 1500 & & 231 & Mesotrophic & $1989-\mathrm{EFI}$ \\
\hline Sempor & 300 & 45 & 77 & Mesotrophic & $1978-I E F$ \\
\hline \multicolumn{6}{|l|}{ East Jawa: } \\
\hline Karangkates & 1500 & 70 & 270 & Mesotrophic & $1972-\mathrm{IEF}$ \\
\hline Selorejo & 400 & 46 & 600 & Mesotrophic & $1970-$ IEF \\
\hline Lahor & 260 & 50 & 300 & Mesotrophic & $1977-I E F$ \\
\hline Wlingi & 380 & 28 & 163 & Mesotrophic & $1977-\mathrm{IEF}$ \\
\hline Bening & 570 & 10 & 11 & Mesotrophic & $1983-I F$ \\
\hline Sengguruh & 290 & 24 & 296 & Mesotrophic & $1987-\mathrm{El}$ \\
\hline \multicolumn{5}{|l|}{ Nusa Tenggara Barat: } & $1983-1$ \\
\hline \multicolumn{6}{|l|}{ South Kalimantan: } \\
\hline Riam Kanan & 9200 & 50 & 25 & Mesotrophic & $1983-\mathrm{IEF}$ \\
\hline \multicolumn{6}{|l|}{ Lampung: } \\
\hline Way Rarem & 1400 & 25 & 60 & Mesotrophic & $1982-I F$ \\
\hline Way Jepara & 220 & $?$ & 60 & Mesotrophic & $1976-I F$ \\
\hline
\end{tabular}

Remarks: I = irrigation; F = flood control; $\mathrm{E}$ = electric power; $\mathrm{D}$ = drinking water

Potential Yield And Fish Diversity Of Lakes And Reservoirs

Potential yield of lakes and reservoirs of Indonesia has been estimated using primary productivity and or morpho-edaphic index (a ratio between conductivity and mean depth) approach (Moreau\&DeSilva, 1991; Oglesby, 1982) (Kartamihardja, 2009). For that purposes, a total number of 27 lakes samples and 46 reservoirs samples were classified into three groups, i.e. large, medium and small water body. The large water body of lakes are lakes with a surface water area more than 10,000 ha; medium water body has a surface water area between $>5000-10,000$ ha; and small water body has a surface water area between $>1000-5000$ ha. The large, medium and small lakes has an average of estimated potential yield of $178.8 \pm 67.1 ; 207.6 \pm 62.2$; and $71.6 \pm 36.4 \mathrm{kgs} / \mathrm{ha} / \mathrm{yr}$, respectively. For the reservoir, the large water body has a surface water area $>1000-10,000$ ha, medium reservoir has a surface water area between $>200-1000$ ha, and small reservoir has a surface water area between $0.5-200$ ha. The large, medium and small reservoirs have an average of estimated potential yield $683.5 \pm 229.1 ; 1328.8 \pm 485.7$ and $2793.7 \pm 1022.9 \mathrm{kgs} /$ ha/yr, respectively. The relationship between potential yield and area of lakes and reservoirs are presented in Figure 1 and 2. The equations were used to estimate the potential fish of the individual lake and reservoir for fisheries development, especially in stock enhancement techniques. Based on these data and information, Kartamihardja, (2009) also estimated the total potential yield of the Indonesian lakes being 328,804 tones/year and reservoirs being 385,304 tones/year. 
Indonesia divides into two ecological regions; western Indonesia is more influenced by Asian fauna, and the east is more influenced by Australasian. Zoogeographically, fish resources of inland waters of Indonesia are divided into fish inhabit the Sundaland, Wallacea zone and Sahulland which were inhabited by more than 1.000 fish species (Kottelat et al., 1995). In the Sunda land more than 358 species of the order Ostariophysi and Labyrinthici dominated inland open waters in Sumatera and Kalimantan (Ondara, 1982).

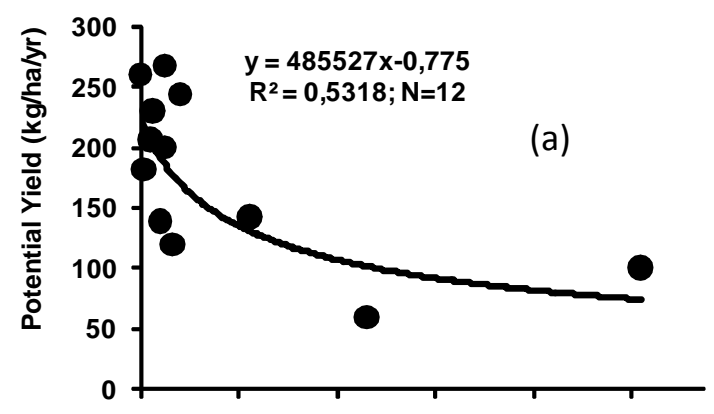

10.00030 .00050 .00070 .00090 .000110 .000 Lake area (ha)
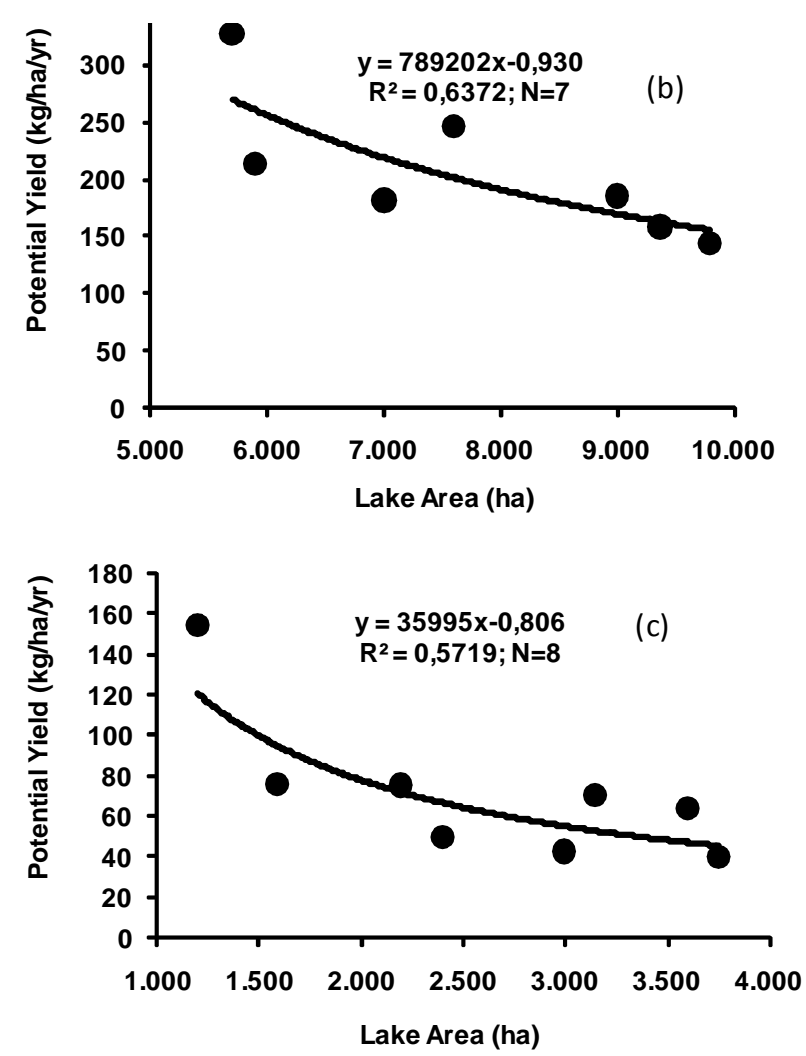

Figure 1. Relationship between lake area and estimated potential yield

Remarks: (a) Large lakes, area: $>10.000$ ha; (b) Medium lakes, area: $>5.000-10.000$ ha; (c) small lakes, area: $>1.000-5.000$ ha
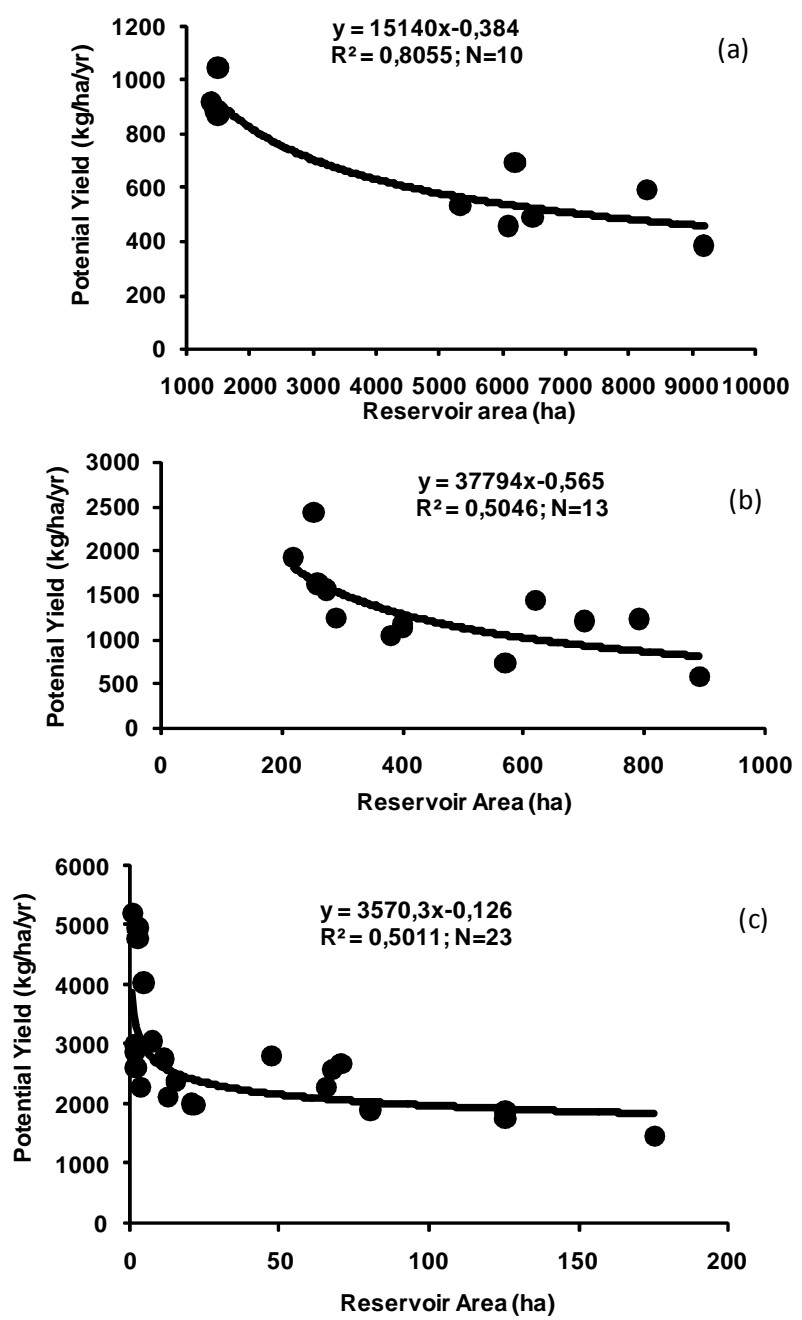

Figure 2. Relationship between reservoir area and potential yield

Remarks: (a) Large reservoirs, area: 1.000-1.000 ha;

(b) Medium reservoirs, area: $>200-1,000$

ha; (c) Small reservoirs, area: $0.5-200$ ha

There are about 310 species of fishes recorded from the rivers and lakes of Wallacea, 75 species of them are endemic. Although little is still known about the fishes of the Moluccas and the Lesser Sunda Islands, 6 species are recorded as endemic. On Sulawesi, there are 69 known species, of which 53 are endemic. The Malili lakes in South Sulawesi, with its complex of deep lakes, rapids and rivers, have at least 15 endemic thelmatherinid fishes, two of them representing endemic genera, three endemic Oryzias, two endemic halfbeaks, and seven endemic gobies.

Most of the species inhabit inlandwaters of Indonesia are riverine species and only some species are the lacustrine. Therefore, number of fish species inhabit the lakes and reservoirs generally less than 
the species inhabit the rivers. This condition is one of the factors caused fish production in lakes and reservoirs being relatively low due to large the pelagic area was not inhabited by fish. Some species dominated the lakes and reservoirs, generally of the cyprinids family such as genus Puntius/Barbonymus, Hampala, Mystacoleucus, Osteochilus; silurids family such as Mystus, Channa; and chiclids, Oreochromis mossambicus.

\section{Fish Stock Enhancement}

Stock enhancement in the meaning of fish introduction in Indonesian lakes has been conducted since Dutch colonization, since an ancient ago (Sarnita, 1986). More than 17 fish species has been stocked into lakes and reservoir of Indonesia (Sarnita, 1986; Sarnita, 1999). Snake head (Channa striata) is the first species introduced into Indonesia from Southern China in 1915, grass carp (Ctenopharyngodon idella) and mud carp (Cirrhinus chinensis) introduced from Malaysia. Common carp (Cyprinus carpio) now becomes one of culture species delivered from China and Japan in 1920.

Fish species stocked in lakes and reservoirs were usually the cultured species such as common carp, Cyprinus carpio; java tilapia (Oreochromis mossambicus; Nille tilapia, $O$. niloticus; snakeskin gouramy, Thrichogaster pectoralis; and three spot gourami, T. trichopterus; java barb, Barbonymus gonionotus; Bitter dregs fish, Osteochilus hasselti; giant gouramy, Osphronemus gouramy; walking catfish, Clarias batrachus; and kissing gouramy, Helostoma temmincki (Sarnita, 1986). List of the fish species introduced and stocked in Indonesian lakes and reservoirs was presented in Table 3.

Java tilapia, Oreochromis mossambicus was introduced to Toba Lake, an oligotrophic and the deep lake in North Sumatera in 1930. The tilapia growth and breed naturally and since 1958 become the dominant species in the total catch. Unfortunately, the java tilapia grow slowly with the body slimmer due to poor of natural food and limitted of littoral habitat (Kartamihardja, 1987).

In Indonesian reservoirs, fish stock enhancement generally conducted since the reservoir impounded. The fish species used in the stock enhancement mostly the culture species, such as tilapia ( $O$. mossambicus and $O$. niloticus), common carp (Cyprinus carpio), giant gouramy (Osphronemus gouramy), java carp (Barbonymus gonionotus), kissing gouramy (Helostoma temminckii), snakeskin gouramy (Trichogaster pectorallis) and three spot gourami (T. trichopterus). Nile tilpia introduced in the reservoirs, generally showed good performance, spawn naturally and increased the total fish catch, such as its happened in Jatiluhur Reservoir, West Java (Kartamihardja \& Hardjamulia, 1985).

Between the introduced species, snake head, common carp, snake skin gouramy (Trichogaster trichopterus) and java tilapia (Oreochromis mossambicus) were species which can grow either in some lakes and reservoirs of Indonesia and dominates the fishers catch.

In some lakes and reservoirs, fish introduction and restocking has prospected in increasing catch, but in a long term success of restocking practice in the context of environmental balance and its support to the poor is fail. Fish introduction which is not based on precautionary approach and limnological characteristics of the water body would negate impact on the degradation of local fish species.

FAO, (1999) reported that through fish stocking and introduction adapted to limnological condition of the water body and ecological balance oriented has increased for about $20 \%$ of fish production of the world inland open waters. In Indonesia, some example of fish stocking and introduction being successful is as follows.

Introduction of common carp to Lake Tondano in North Sulawesi in period 1985-1991, yielded 60\% from total fish catch of $340 \mathrm{~kg} / \mathrm{ha}$ (Sukadi\& Kartamihardja, 1995). In 1937, java barb (B. gonionotus) introduced to lake Tempe in South Sulawesi and in 1940 and 1948 has yielded of 3,650 tonnes and 25,000 tones, respectively (Sarnita, 1986). Total fish production in that lake increasing from year to year and in 19631975, the average fish production reached $900 \mathrm{kgs} /$ ha/yr (Sarnita, 1999). After 1995, the fish production was dominated by Nile tilapia which was introduced in 1992.

Since 1999, stock enhancement of Indonesian lakes and reservoirs was generally based on scientific data and information about productivity and ecological niche of the waters body, structure of fish community, life cycle and biology of the fish stocked (Kartamihardja, 2007). Some successful of fish stock enhancement in some lakes and reservoirs are as follows. 
Table 3. List of fish species introduced and stocked in Indonesian lakes and reservoirs

\begin{tabular}{|c|c|c|c|c|}
\hline No & Common Name & Scientific Name & Lakes/ Reservoirs & Remarks \\
\hline \multirow[t]{5}{*}{1} & Common carp & Cyprinus carpio & L. Toba & $\begin{array}{l}\text { In 1905, } 1937 \text { found in great number, early } 1950 \\
\text { decreasing }\end{array}$ \\
\hline & & & L. Tempe & introduced in 1960-1970, established until 1995 \\
\hline & & & R. Selorejo & $\begin{array}{l}\text { Introduced in 1971-1980, growth well, not reproduced } \\
\text { naturally }\end{array}$ \\
\hline & & & R. Lahor & $\begin{array}{l}\text { Introduced in 1971-1980, growth well, not reproduced } \\
\text { naturally }\end{array}$ \\
\hline & & & R. Karangkates & $\begin{array}{l}\text { Introduced in 1971-1980, growth well, not reproduced } \\
\text { naturally }\end{array}$ \\
\hline \multirow[t]{3}{*}{2} & Java Tilapia & Oreochromis mossambicus & L. Toba & Early 1940 in L. Toba, established until 2003; \\
\hline & & & L. Limboto & introduced in 1944, established since 1950 \\
\hline & & & L. Lindu & introduced in early 1950 , established \\
\hline \multirow[t]{3}{*}{3} & Nile tilapia & Oreochromis niloticus & R. Karangkates & introduced in 1979, well established \\
\hline & & & $\begin{array}{l}\text { R. Selorejo } \\
\text { R. Lahor }\end{array}$ & $\begin{array}{l}\text { introduced in 1979, well established } \\
\text { introduced in 1979, well established }\end{array}$ \\
\hline & & & R. Jatiluhur & introduced in 1965, well established \\
\hline 4 & Giant gouramy & Osphronrmus gouramy & L. Toba & introduced in 1920. not established \\
\hline \multirow[t]{2}{*}{5} & Snake skin gourami & Trichogaster pectoralis & $\begin{array}{l}\text { R. Jatiluhur } \\
\text { L. Toba }\end{array}$ & $\begin{array}{l}\text { introduced in 1965, not established } \\
\text { introduced in 1920. not established }\end{array}$ \\
\hline & & & L. Tempe & introduced in 1937 and 1940, well established \\
\hline 6 & Three spot gourami & Trichogaster trichopterus & $\begin{array}{l}\text { R. Jatiluhur } \\
\text { L. Tondano }\end{array}$ & $\begin{array}{l}\text { introduced in 1965, not established } \\
\text { introduced in 1925. established since } 1935\end{array}$ \\
\hline 7 & Bitter dregs fish & Osteochilus hasselti & Crater Lake in Maluku & Introduced in 1929, not established \\
\hline 8 & Kissing gouramy & Helostoma temminckii & L. Tempe & introduced in 1925. established since 1940 \\
\hline 9 & Java carp & Barbonymus gonionotus & L. Tempe & introduced in 1937, well established until 1995 \\
\hline \multirow[t]{2}{*}{10} & Milk fish & Chanos chanos & $\begin{array}{l}\text { R. Lahor } \\
\text { R. Jatiluhur }\end{array}$ & $\begin{array}{l}\text { introduced in } 1978 \text {, established } \\
\text { Introduced in } 2008 \text {, to mitigate a negative impact of cage } \\
\text { culture, fast growth }\end{array}$ \\
\hline & & & R. Cirata & $\begin{array}{l}\text { Introduced in } 2008 \text {, to mitigate a negative impact of cage } \\
\text { culture, fast growth }\end{array}$ \\
\hline 11 & Grass carp & Ctenopharyngodon idella & $\begin{array}{l}\text { L. Batur } \\
\text { L. Kerinci }\end{array}$ & $\begin{array}{l}\text { Introduced in } 2009 \text {, slow growth } \\
\text { introduced in 1995/96, succes to control aquatic weed, } \\
\text { water hyacinth }\end{array}$ \\
\hline 12 & Bilih fish & Mystacoleucus padangensis & L. Toba & $\begin{array}{l}\text { transflanted in 2003, well established since } 2005 \text { and } \\
\text { dominated yield }\end{array}$ \\
\hline 13 & Siamese catfish & Pangasionodon hypopthalmus & R. Wonogiri & $\begin{array}{l}\text { introduced in 1999-2003, well established, spawn } \\
\text { naturally }\end{array}$ \\
\hline \multirow[t]{2}{*}{14} & Silver carp & Hypopthalmichthys molitrix & R. Cirata & $\begin{array}{l}\text { Introduced in } 2007 \text { to mitigate a negative impact of cage } \\
\text { culture, fast growth but not prefered as food }\end{array}$ \\
\hline & & & R. Jatiluhur & $\begin{array}{l}\text { Introduced in } 2007 \text { to mitigate a negative impact of cage } \\
\text { culture, fast growth but not prefered as food }\end{array}$ \\
\hline
\end{tabular}

Giant freshwater prawn (Macrobrachium rosernbergii) introduced in Darma reservoir, West Java in 2003 yielded $337,65 \mathrm{kgs}$ with the value of 13,5 million rupiahs in 2004 even though the seed prawn stocked was only 26,500 tails or $26,5 \%$ from the optimum amounts of stocking (Kartamihardja et al., 2004). If the prawn stocking is done optimally, it is estimated that the prawn value production of $70-140$ million rupiahs per year would be achieved and be an additional income for 120 fishers.

In the period 1999-2002, about 36,450 seeds of Siamese catfish (Pangasionodon hypopthalmus) have been introduced into Wonogiri reservoir in Central Java and since 2003 the catfish production increased gradually. In 2004, the Siamese caught were 112,215 tones which the value equal to 785.5 million rupiahs adding the fisher income for about 1.2 million rupiahs per fisher per year (Kartamihardja and Purnomo, 2004). The Siamese catfish grow fast and this fecundity at the total length between $67.0-82.7 \mathrm{~cm}$ and the weight between 3000-5500 grams rranged between 271,700$1,177,250$ eggs (Adjie et al., 2006). The Siamese catfish can spawn naturally and the seed distributed in the mouth of Keduwang and Tirtomoyo River, one of the inlet river. In the period 2005-2010, the Siamese catfish production showed the leveling off, reached between 142.925-191.210 tones as presented in Figure 3. This is indicated that the rate of Siamese catfish recruitment from natural spawning lower than that the rate of Siamese catfish exploitation (Kartamihardja et al., 2011). The introducing bilih fish has been able to provide the positive impact on social and economic aspects of the society surrounding the Lake Toba (Koeshendrajana, 2011). 


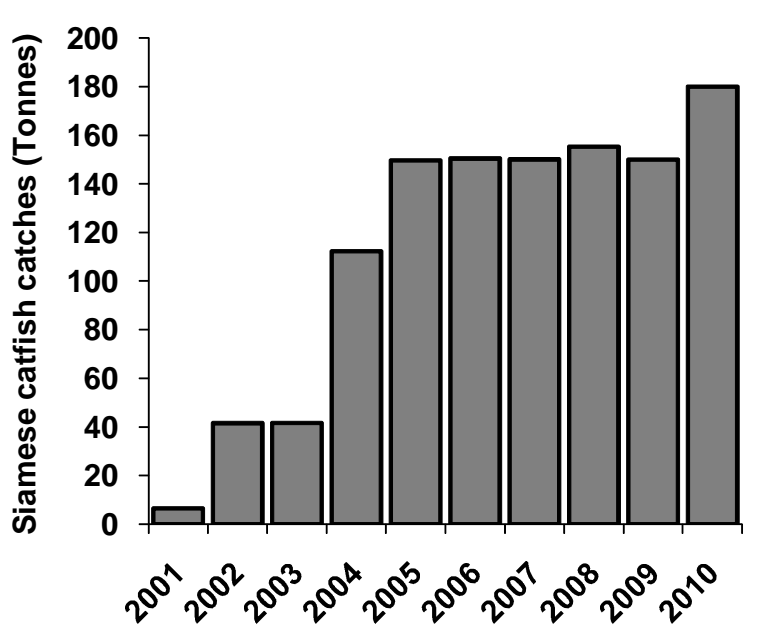

Figure 3. Siamese catfish (P. hypophthalmus) catches in Wonogiri Reservoir

In 2003, bilih fish (Mystacoleucus padangensis), an endemic fish from Lake Singkarak in West Sumatra were introduced to lake Toba in North Sumatra. The species grow and breed naturally and inhabit the pelagic area (Kartamihardja \& Purnomo, 2006). Since 2005 the bilih production fastly increases from 653,6 tonnes to be 30,000 tonnes in 2010 as shown in Figure 4 (Kartamihardja \& Sarnita, 2010; Wijopriono et al., 2010).

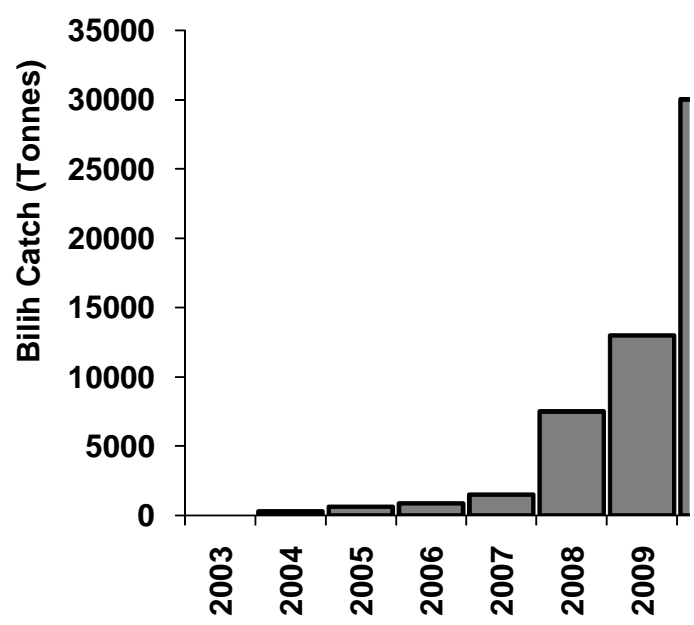

Figure 4. Bilih fish, M. padangensis catches in Toba Lake

To control aquatic weed, Echhornia crassipes in Kerinci Lake, Jambi, a total number of 28,500 grass carp fingerlings with the total length ranged between 5-12 cm has been introduced in 1995-1996. After two years stocking, nearly 3.000 hectares of water hyacinth covering the lake is clear significantly of the weed (Hartoto \& Sumantadinata, 1998).
Mitigating the negative impact of intensive cage fish culture using milk fish, Chanos chanos has been conducted in Jatiluhur reservoir, West Java in 20082009. The milk fish fingerling with a total number of 2 millions (in 2008) and 4 millions (in 2009) were multiple stocked in the reservoir. The abundance and biomass of phytoplankton decreased significantly after one month of the stocking. The nutrient of nitrogen and phosphor content were also significantly decreased so that there is no blooming algae which frequently occurred and also the mass died of fish in the cage culture has not been occurred (Kartamihardja et al., 2010a).

\section{DISCUSSION}

Lakes and reservoirs of Indonesia has differed limnological characteristics between one water body and the other waters. Its mean that lake characteristics differs from reservoirs characteristics which resulted differences in productivity and potential fish yield. As a result, fish stock enhancement conducted should be adapted to the limnological characteristics of the lake or reservoir. In the deep lake where the area of littoral zone is limited, the fish species stock should be a lacustrine and plankton feeder species which can inhabit the limnetic zone and utilize the plankton abundance.

Theoretically, small lake should be highest productivity than medium or large lake but in this case the small lake has lower productivity because the lake samples were crater or caldera lake and deep lakes. The small reservoirs including small shallow lakes, generally have high productivity (potential fish yield) compared to those bigger areas. Stock enhancement in those small water bodies, should be fish introduction and or development of culture based fisheries. The species introduced should be plankton feeder and or herbivore where the fish stocked can utilize the natural food, especially plankton. The bigger reservoirs which were multipurpose reservoir where fisheries placed in the secondary function, stock enhancement activity should include restocking and or introduction of fish species, rehabilitation of spawning habitat and conservation.

As stated before, practice of fish stock enhancement through fish stocking and introduction have been done for long time ago. However, fish introduction done generally haves the ceremonial character, only gives the subsidy for fisher and have never been monitored and or was evaluated about the success or the failure (Kartamihardja, 2000). Fish stocking paradigm which only stocked fish without considering limnological condition of the water body, 
preference of the society for the fish and its economics value, possibility that stocking negatively impact on local fish population (Maskur et al., 2010). Until recently, study on the impact of fish introduction on the native fish population as well as on its genetics has not been conducted. For that purposes, the Government should push and support the sound environmentally program as well as study on that matter. For stock enhancement successful, the central management system needs to be changed to involve public participation so that technical management of the fisheries will increase the fish production, ecologically safe, and economically profitable.

Some problems come up in the stock enhancement applied in Indonesian lakes and reservoirs are low understanding of stock enhancement by the stake holders; stock enhancement applied has not been based on scientific data and information; fish stocking was done ceremonially by government; number of fish seed stocked was not optimum; hatchery of local species was minimal; impact assessment, monitoring and evaluation have not been conducted; cost-benefit has not been calculated (Kartamihardja et al., 2010b). Campaign of the best practice of stock enhancement to the stakeholders should be conducted before fish stocking was done. The fishers group as a management unit and a key player in the management of the fisheries should be established and educated.

In lakes and reservoirs with multipurpose, an integrated management should be applied and management of fishery is a part of management of lakes or reservoirs as a whole (Kartamihardja \& Nurhakim, 2005). Management measures of the lakes or reservoirs fisheries should include management of fish population, management of fishery and management of habitat. To know management effectively, periodical monitoring and evaluation need to be done to all production process start from resource aspects, fishery, fish culture, fish harvest, handling, marketing, socio-economic and law enforcement and regulation (Kartamihardja et al., 2010b). Fisheries management developed should be co-management regime with participation of the society.

The successful of fish stock enhancement in some lakes and reservoirs of Indonesia have been supported by some factors, i.e., the stocking program was done regularly or the fish stocked can spawn naturally; the seed stocked at an optimum level; regulating of fish catch, developing of market system, strengthen of management institution and implementation of fisheries co-management.

\section{CONCLUSION}

Indonesian lakes and reservoirs have different limnological characteristics and also the productivity (potential fish yield). In the future, therefore, the fish stock enhancement should be based on scientific evidence. The Government should facilitate and support in providing local fish seed for restocking purposes. Introduction of fish species should be done with precautionary approach especially in lakes of Sulawesi and Papua inhabited by endemic species. Basic research in lakes and reservoirs productivity, niche ecology, structure of fish community and its trophic level should be conducted. Co-management regime of the lake and reservoir fisheries should be developed.

\section{ACKNOWLEDGEMENTS}

This paper has been presented in the Worshop on Consultation on Development Trends in Fisheries and Aquaculture in Asian Lakes and Reservoirs, held at Wuhan, PR China on 20th-23rd September 2011. I would like to thanks to Prof. Sena S. deSilva, Director General of NACA for giving me opportunity to attend the workshop.

\section{REFERENCES}

Adjie, S., A. D. Utomo, N. Muflikhah \& Krismono 2006. Studi Biologi Ikan Jambal Siam (Pangasius hypophthalmus) di Bengawan Solo Bagian Hulu (Study on biology of siamese catfish, $P$. hypophthalmus in Upper part of Solo River). Pros. Forum Perairan Umum Indonesia III. p. 75-84.

FAO (Food and Agriculture Organisation). 1999. Review of the state of world fishery resources: inland fisheries. FAO Fisheries Circular. No. 942. Rome, FAO. 53 p.

Hartoto, D.I. \& K. Sumantadinata. 1998. Biomanipulation of water hyacinth (Eichhornia crassipes) in Lake Kerinci using grass carp (Ctenopharyngodon idella). 2nd Monograph. Research and Dev Center for Limnology, Indonesian Institute of Sciences. Bogor. $20 \mathrm{p}$.

Kartamihardja, E.S., K. Purnomo, S. Koeshendrajana \& C. Umar. 2011. Karakteristik Limnologis, Perkembangan Populasi Ikan Patin Siam (Pangasionodon hypophthalmus) introduksi dan perikanan di Waduk Wonogiri, Jawa Tengah (Limnological characteristics, population growth of stripped catfish, Pangasianodon hypophthalmus introduced and fisheries of Wonogiri Reservoir, 
Central Java). J. Kebijak. Perikan. Ind (Indonesian Fisheries Policies Journal). 3 (1): 37-50.

Kartamihardja, E.S.\& A.S. Sarnita. 2010. Populasi Ikan Bilih: Keberhasilan introduksi ikan, Implikasi pengelolaan dan prospek masa depan (Bilih Fish population in Toba Lake: Sucessful fish introduction, management implication and future prosfect). Research Center for Fisheries Management and Conservation, Agency Research and Development for Marine and Fisheries. MMAF Rep. Indonesia. 50 p. (in Indonesia).

Kartamihardja E. S., M. Maskur, F. Sukadi, C. Umar, F. B. Davy, Sena S. \& De Silva. 2010a. Mitigating Negative Environmental Impact from Intensive Cage Culture Using Stock Enhancement: Case Study on Djuanda Reservoir, West Java Indonesia (inpress).

Kartamihardja, E.S., K. Purnomo, D.W.H. Tjahjo, C. Umar, M.T.D. Sunarno \& S. Koeshendrajana. 2010b. Petunjuk Teknis, Pemacuan sumberdaya ikan di Perairan Umum Daratan Indonesia (Technical Guideline, Fisheries Enhancement at Inland open waters of Indonesia). Research Center for Fisheries Management and Conservation, Agency Research and Development for Marine and Fisheries. MMAF Rep. Indonesia. 72p. (in Indonesia).

Kartamihardja, E.S. 2009. Pendugaan Potensi Produksi Ikan di Perairan Danau dan Waduk Indonesia untuk Pengembangan Perikanan Tangkap (Estimated Potential Fish Yield of Indonesian Lakes and Reservoirs for fisheries development). Technical Report. Research Center for Fisheries Management and Fish Resources Conservation. Agency Research and Development for Marine and Fisheries. MMAF Rep. Indonesia (in Indonesia). $20 \mathrm{p}$.

Kartamihardja, E.S. 2007. Pemacuan stok ikan: Teknologi pilihan untuk meningkatkan produksi perikanan tangkap di Perairan Umum Daratan Indonesia (Fish stock enhancement: optional technology for increasing fisheries production in inland open waters of Indonesia). J. Kebijak. Perikan. Ind. (Indonesian Fisheries Policies Journal). 1 (1): 1-10.

Kartamihardja, E.S. \& K. Purnomo. 2006. Penyelamatan populasi ikan bilih ke habitatnya yang baru di Danau Toba (Sustaining bilih fish population to a new habitat at Toba Lake).
Demersal. Dari Laut untuk Pembangunan. Edisi Maret 2006. Pusdatin, DKP. 8 p.

Kartamihardja, E.S. 2006. Status Kondisi Lingkungan Perairan Umum Daratan Indonesia sebagai Habitat Ikan (Status of environmental condition of Indonesian Inland open waters as fish habitat). Paper presented in Limnology Forum, Research Center for Limnology, Indonesian Institute of Sciences. Jakarta 6th December 2006. (in Indonesia).14 p.

Kartamihardja, E.S. \& S. Nurhakim. 2005. The Need For Integrated Fisheries Management Plan Of Cascade Reservoirs At Citarum River Basin. Paper Presented at the Seminar on Integrated Water Resources Management, January 20, 2005. DGA., Jakarta (unpublish).

Kartamihardja, E.S. \& K. Purnomo. 2004. Keberhasilan introduksi ikan patin siam (Pangasius hypopthalmus) dan dampaknya terhadap komposisi dan hasil tangkapan ikan di Waduk Wonogiri, Jawa Tengah (The successful of siamese catfish introduced and its impact on fish yield composition at Wonigiri Reservoir, Central Java). Pros. Forum Perairan Umum Ke-1. Balai Riset Perikanan Perairan Umum, PRPT, BRKP, DKP.

Kartamihardja, E.S., K. Purnomo, H. Satria, D.W.H.Tjahjo, \& S.E. Purnamaningtyas. 2004. Peningkatan stok ikan patin siam (Pangasius hypophthalmus) di Waduk Wonogiri, Ikan baung (Mystus nemurus) di Waduk Wadaslintang dan udang galah (Macrobrachium rosernbergii) di waduk Darma (Stock enhancement of Siamese catfish in Wonogiri reservoir, green catfish in Wadaslintang reservoir and Giant freshwater prawn in Darma reservoir). Pros. Hasil Penelitian Tahun 2004. Pusat Riset Perikanan Tangkap, BRKP, DKP. 159-172. (in Indonesia).

Kartamihardja, E.S. 2000. Strategi peningkatan stok ikan di perairan danau dan waduk Indonesia (Strategy of fish stock enhancement in Indonesian lakes and reservoirs). Pros. Semiloka Nasional Pengelolaan dan Pemanfaatan Danau dan Waduk, Jurusan Perikanan Fak. Pertanian UNPAD, Bandung 7 Nopember 2000. 15 p.

Kartamihardja, E.S., Krismono \& K. Purnomo. 1992. Kondisi Ekologis dan potensi sumber daya perikanan danau dan waduk (Ecological condition and potential fish yield of lakes and reservoirs). Pros. Temu Karya IImiah Perikanan Perairan 
Umum, Pengkajian Potensi dan Prospek Pengembangan Perikanan Perairan Umum Sumatera Bagian Selatan, Palembang 12-13 Februari 1992. Puslitbang Perikanan No.26, 1992. Jakarta. p. 37-45.

Kartamihardja, E.S. 1987. Potensi produksi ikan dan pengelolaan perikanan Danau Toba (Potential fish yield and fisheries management of Toba Lake). Bull. Penel. Perikanan Darat. 6 (1): 1-10.

Kartamihardja, E.S. \& A. Hardjamulia. 1985. Konstribusi penebaran ikan nila (O. niloticus) terhadap produksi ikan Waduk Jatiluhur, Jawa Barat (Contribution of Nile tilapia, O. niloticus) stocking to fish production of man-made lake Jatiluhur, West Java). Bull. Pen. Perikan. Darat, $4(1): 37-40$.

Koeshendradjana, S. 2011. Kebijakan dan strategi pengelolaan perikanan tangkap di Danau Toba pasca introduksi ikan bilih (Policies and strategies for fishery management in the Toba Lake post introducing of Bilih fish). J. Kebijak. Perikan. Ind. $3(1): 1-12$.

Kottelat, M, A.J. Whitten, S.R. Kartikasari \& S. Wirjoatmojo. 1995. Freshwater Fishes Of Western Indonesia And Sulawesi, Ikan Air Tawar Indonesia Bagian Barat Dan Sulawesi. Periplus edition (HK) Ltd. $293 p+84$ plate.

Lehmusluoto, P. \& B. Machbub. 1977. National Inventory of the major lakes and reservoirs in Indonesia. General Limnology. Revised Ed. Expedition Indodanau Tech. Rep. Res. Inst. Water Resources Dev. Rep of Indonesia and Dept Limnology and Envi. Protect., Univ. Helsinki. Finland, $72 \mathrm{p}$.

Maskur, M., E.S. Kartamihardja \& S. Koeshendrajana. 2010. Inland Fisheries Resources Enhancement and Conservation in Indonesia. In M. Weimin, S.S. De Silva and B. Davy (eds). Inland Fisheries Enhancement and Conservation in Asia.
RAP Publication 2010/22. FAO., UN, Regional Office for Asia and the Pacific, Bangkok. p. 61-76.

Moreau, J. \& S.S. DeSilva. 1991. Predictive fish yield models for lakes and reservoirs of the Philippines, Sri Lanka, and Thailand. FAO Fish. Tech. Pap. No.319, Rome.

Oglesby, R.T. 1982. The mophoedaphic index and reservoir fish production. Trans. Am. Fish. Soc., 111:113-40.

Ondara. 1982. Beberapa catatan tentang perairan tawar dan fauna ikannya di Indonesia (Some notes on freshwaters fish fauna of Indonesia). Pros. Seminar Perikanan Perairan Umum, Jakarta, 1921 Agustus 1981. Puslitbang Perikanan, Badan Litbang Pertanian. p. 46-56.

Sarnita, A.S. 1986. Introduction and stocking of fish in lakes and reservoirs in Southeast Asian countries with special reference to Indonesia. Reports and Papers presented at the IPFC expert consultation on Inland Fisheries of the Larger IndoPacific Islands. Bangkok Thailand, 4-6 August 1986. FAO Fish. Rep. No. 371 Suppl. FIRI/R371.

Sarnita, A.S. 1999. Introduction and stocking of freshwater fishes into inland waters of Indonesia. In: W.L.T. vanDensen \& M.J. Morris (eds) Fish and fisheries of lakes and reservoirs in Southeast Asia and Africa. Westbury Pub., Otley, UK. p.143150.

Sukadi, M. F. \& E.S. Kartamihardja. 1995. Inland fisheries management of lakes and reservoirs with multiple uses in Indonesia. Regional Symposium on sustainable development of inland fisheries under environmental constrains, Bangkok, Thailand, 19-21 October 1994, FAO, UN.

Wijopriono, K. Purnomo, E.S. Kartamihardja, \& Z. Fahmi. 2010. Fishery resources and ecology of Toba Lake. Ind. Fish. Res, J. 16 (1):7-14. 